\title{
Analisis pengaruh pengeluaran pemerintah daerah sektor pendidikan dan kesehatan serta infrastruktur terhadap tingkat pengangguran serta tingkat kemiskinan
}

\author{
Mardiana $^{1}$, Theresia Militina ${ }^{2}$, Anis Rachma Utary ${ }^{3}$ \\ Magister Ilmu Ekonomi, Fakultas Ekonomi dan Bisnis Universitas Mulawarman, Samarinda. \\ Email: Mardiana@mhs.feb.unmul.ac.id \\ ${ }^{2}$ Email: theresia.militina@feb.unmul.ac.id \\ ${ }^{3}$ Email: anis.rachma.utary@feb.unmul.ac.id
}

\begin{abstract}
Abstrak
Penelitian ini bertujuan untuk menganalisis dan mengetahui pengaruh pengeluaran pemerintah sektor pendidikan, kesehatan, dan infrastruktur terhadap tingkat pengangguran dan tingkat kemiskinan di Provinisi Kalimantan Timur. Data yang digunakan dalam penelitian ini adalah data sekunder pada tahun 2006-2015. Alat analisis yang digunakan adalah analisis jalur (path analisis). Perangkat lunak yang digunakan untuk melakukan analisis adalah IBM SPSS Versi 17.0. Hasil Penelitian menunjukkan bahwa dalam mempengaruhi tingkat pengangguran, Pengeluaran anggaran bidang pendidikan berpengaruh langsung dan tidak signifikan dengan nilai pengaruh -0.570 dan signifikansi $0,216>$ 0,050 . Pengeluaran anggaran bidang kesehatan berpengaruh langsung dan signifikan dengan nilai pengaruh $-0,800$ dan signifikansi $0,047<0,050$. Pengeluaran anggaran bidang infrastruktur berpengaruh langsung dan tidak signifikan dengan nilai pengaruh $-0,013$ dan signifikansi $0,970>$ 0,050. Dalam mempengaruhi tingkat kemiskinan, Pengeluaran anggaran bidang pendidikan berpengaruh langsung dan tidak signifikan dengan nilai pengaruh 0,239 dan signifikansi 0,623 > 0,050 . Pengeluaran anggaran bidang kesehatan berpengaruh langsung dan signifikan dengan nilai pengaruh $-0,888$, dan signifikansi $0,033<0,050$. Pengeluaran anggaran bidang infrastruktur berpengaruh langsung dan tidak signifikan dengan nilai pengaruh $-0,075$, dan signifikansi $0,826>$ 0,050 . Pengangguran Terbuka berpengaruh langsung dan tidak signifikan dengan nilai 0,248 dan signifikansi 0,555 >0,050.
\end{abstract}

Kata Kunci: Pengeluaran anggaran; tingkat pengangguran

\section{Analysis of the influence of local government spending on education and health and infrastructure on unemployment and poverty levels}

\begin{abstract}
This study aimed to analyze and determine the effect of government spending sectors of education, health, and infrastructure on the level of unemployment and poverty rates in East Kalimantan province ranked. The data used in this research is secondary data in 2006-2015. The analytical tool used is path analysis (path analysis). The software used to perform the analysis is IBM SPSS Version 17.0. Research shows that in affecting the unemployment rate, the allocation of the education budget directly and significantly affect the value and significance of the influence -0.570, $0.216>0.050$. health sector budget allocations directly and significantly affect the value and significance of the effect of $-0.800,0.047<0.050$. budget allocation of infrastructure directly and significantly affect the value of the influence and significance $-0.013,0.970>0.050$. In influencing the level of poverty, the education budget allocations directly and significantly affect the value of the influence and significance 0.239, 0.623>0.050. health sector budget allocations directly and significantly affect the value of -0.888 influence and significance of $0.033<0.050$.
\end{abstract}

Keywords: Budget allocation; unemployment rate 


\section{PENDAHULUAN}

Kemiskinan adalah keadaan dimana terjadi ketidakmampuan seseorang dalam memenuhi kebutuhan dasar seperti pakaian, makanan, pendidikan, kesehatan, dan tempat tinggal. Kemiskinan dialami hampir di seluruh negara di dunia termasuk Indonesia. Daerah yang kaya akan sumber daya alam seperti Kalimantan Timur pun juga mengalami kemiskinan yang jika tidak segera disikapi, dikhawatirkan akan berdampak terhadap pembangunan daerah. Masalah kemiskinan di Kaltim sendiri terjadi dikarenakan tingginya angka perpindahan penduduk dari provinsi lain ke Kaltim namun tidak dibekali dengan keterampilan khusus yang dibutuhkan lapangan kerja yang tersedia. Sehingga bukannya meningkatkan penghasilan daerah dan mensejahterakan rakyatnya yang terjadi malah kebalikannya, banyak orang yang menganggur dan keadaan inilah yang memicu timbulnya masalah kemiskinan. Masalah keimigrasian inilah yang menjadi persoalan serius dan seharusnya mendapat perhatian yang cukup dari pemerintah baik itu provinsi maupun daerah.

Tingginya tingkat pengguran di Kaltim disebabkan beberapa hal, selain pertumbuhan ekonomi yang lemah juga adanya persaingan lapangan kerja. Jadi salah satu alternatif untuk menekan pengangguran terbuka di Kaltim adanya subsidi di bidang pertanian, karena bidang tersebut yang paling banyak menyerap tenaga kerja. Sedangkan bidang pertambangan dan galian hanya 8 persen dalam penyerapan tenaga kerja, selain itu perlunya peningkatan Sumber Daya Manusia (SDM) yang berkualitas agar mampu bersaing dengan SDM yang datang dari luar Kaltim. Jika pemerintah meningkatkan kualitas pendidikan seperti mengadakan pembinaan terhadap siswa SMA, SMK, SLTA dan sederajat untuk mengetahui ingin menjadi apa mereka ke depannya. Kemudian diadakannya pelatihan agar mereka siap bekerja jika sudah lulus atau mereka ingin melanjutkan kuliah sambil bekerja yang bisa meningkatkan pengahasilan daerah juga tentunya. Lalu peningkatan transpotasi juga diperlukan karena jarak antar kota yang sangat jauh, misalnya ada pekerja yang bertempat tinggal di Tarakan namun lokasi kerja berada di Samarinda. Keadaan inilah yang terkadang membuat pekerja kebingungan. Dana untuk para wirausahawan juga harus dialokasikan, mungkin dengan mereka berwirausaha malah membuka lapangan kerja bagi mereka pemuda-pemuda yang menganggur. Subsidi pun sebaiknya diatur secara lancar agar tak ada rakyat yang menuntut jatah subsidi yang belum diberikan. Oleh sebab itu peran pengalokasian APBD untuk bidang pendidikan, infrastruktur, dan kesehatan, mutlak diperlukan untuk mengurangi tingkat kemiskinan dan pengangguran di Kaltim.

Perbaikan kualitas modal manusia tergantung pada tersedianya infrastruktur untuk menunjang investasi pada sumber daya manusia. Perumahan dan transportasi merupakan barang publik yang dapat disediakan pemerintah dalam rangka pemenuhan kebutuhan masyarakat. Ketersediaan perumahan yang layak akan membuat kualitas hidup masyarakat menjadi lebih baik karena dengan rumah yang layak dapat mendukung kesehatan dan pada akhirnya akan meningkatkan produktifitas sumber daya manusia. Jaringan transportasi yang terintegrasi dengan baik akan melancarkan distribusi kegiatan ekonomi dan secara jangka panjang dapat menjadi media pemerataan pembanguna. Menurut Deni Friawan (2008) ada tiga alasan utama mengapa infrastruktur penting dalam sebuah integrasi ekonomi. Alasan pertama adalah ketersedian infrastruktur yang baru merupakan mesin utama pembangunan ekonomi. Kedua, untuk memperoleh manfaat yang penuh dari integrasi, ketersediaan jaringan infrastruktur sangat penting dalam memperlancar aktifitas perdagangan dan investasi. Alasan ketiga adalah perhatian terhadap perbaikan infrastruktur juga penting untuk mengatasi kesenjangan pembangunan ekonomi antar negara. Infrastruktur terdiri dari beberapa subbidang, infrastruktur dalam bentuk perumahan dan transportasi merupakan cukup penting untuk menunjang kehidupan masyarakat.

\section{METODE}

\section{Definisi Operasional}

Definisi operasional merupakan konsep normatif yang telah dikemukakan dalam bab terdahulu, maksud dilakukan perumusan operasional ini tidak lain agar data yang dipergunakan dalam analisis nantinya dapat memberikan gambaran yang jelas dan tidak memberikan penafsiran yang bermacammacam terhadap data tersebut. Adapun rincian variable yang akan diberikan definisi operasional, sebagai berikut: 
a) Pengeluaran pemerintah bidang pendidikan (X1) yang dimaksud dalam penelitian ini adalah pengeluaran untuk pembangunan sarana dan prasarana pendidikan yang dilakukan oleh Pemerintah Kalimantan Timur yang berasal dari pembagian anggaran dari APBN maupun diperoleh dari PAD Kalimantan Timur. Selanjutnya dialokasikan kepada seluruh SKPD terkait dalam hal ini bidang pendidikan guna peningkatan tingkat pendidikan masyarakat Kalimantan Timur, dalam rentan waktu 2005-2014.

b) Pengeluaran pemerintah bidang kesehatan (X2) yang dimaksud dalam penelitian ini adalah pengeluaran untuk pembangunan sarana dan prasarana kesehatan yang dilakukan oleh Pemerintah Kalimantan Timur berasal dari pembagian anggaran dari APBN maupun diperoleh dari PAD Kalimantan Timur. Selanjutnya dialokasikan kepada seluruh SKPD terkait dalam hal ini bidang kesehatan guna peningkatan tingkat kesehatan masyarakat Kalimantan Timur, dalam rentan waktu 2005-2014.

c) Pengeluaran pemerintah bidang infrastruktur (X3) yang dimaksud dalam penelitian ini adalah pengeluaran untuk pembangunan fasilitas infrastruktur yang dilakukan oleh pemerintah Kalimantan Timur yang berasal dari pembagian anggaran dari APBN maupun diperoleh dari PAD Kalimantan Timur. Selanjutnya dialokasikan kepada seluruh SKPD terkait dalam hal ini bidang perbaikan dan pembangunan infrastruktur guna peningkatan tingkat pelayanan publik masyarakat Kalimantan Timur, dalam rentan waktu 2005-2014.

d) Pengangguran terbuka (Y1) yang dimaksud dalam penelitian ini adalah perkembangan kondisi masyarakat yang mengalami pengangguran atau tidak memiliki pekerjaan dalam usia produktif di wilayah Kalimantan Timur yang terdiri dari 10 kabupaten/kota. Dalam rentan waktu 2005-2014.

e) Tingkat Kemiskinan (Y2) adalah ketidakmampuan dari sisi ekonomi untuk memenuhi kebutuhan dasar makanan dan bukan makanan yang diukur dari sisi pengeluaran. Jadi Penduduk Miskin adalah penduduk yang memiliki rata-rata pengeluaran perkapita perbulan dibawah garis kemiskinan yang berada di wilayah Kalimantan Timur yang terdiri dari 10 kabupaten/kota. dalam rentan waktu 2005-2014.

\section{Model Analisis Jalur (path Analysis)}

Model yang digunakan dalam penelitian ini adalah model path analysis menurut Sugiyono (2008: 297) mengemukakan bahwa analisis jalur digunakan bertujuan untuk melakukan dan menguji model hubungan antara variabel yang berbentuk sebab akibat (bukan bentuk hubungan interaktif) dengan demikian dalam model hubungan antara variabel tersebut terdapat variabel independent dalam hal ini di sebut variabel eksogen dan variabel endogen. Melalui analisis jalur ini akan dapat diketahui jalur mana yang paling tepat dan singkat suatu variabel independent menuju variabel dependent.

Teknik analisis jalur dalam penelitian ini digunakan untuk menguji bersanya sumbangan yang ditunjukan oleh koefisien jalur pada setiap diagram jalur dari hubungan masing-masing struktur yang terdiri dari:

$$
\begin{aligned}
& \mathrm{Y} 1=\rho \mathrm{Y} 1 \mathrm{X} 1+\rho \mathrm{Y} 1 \mathrm{X} 2+\rho \mathrm{Y} 1 \mathrm{X} 3+\varepsilon 1 \\
& \mathrm{Y} 2=\rho \mathrm{Y} 2 \mathrm{X} 1+\rho \mathrm{Y} 2 \mathrm{X} 2+\rho \mathrm{Y} 2 \mathrm{X} 3+\rho \mathrm{Y} 2 \mathrm{Y} 1+\varepsilon 2 \\
& \text { dimana: } \\
& \mathrm{X} 1=\text { Pengeluaran Pemerintah Bidang Pendidikan } \\
& \mathrm{X} 2=\text { Pengeluaran Pemerintah Bidang Kesehatan } \\
& \mathrm{X} 3=\text { Pengeluaran Pemerintah Bidang Infrastruktur } \\
& \mathrm{Y} 1=\text { Pengangguran Terbuka } \\
& \mathrm{Y} 2=\text { Tingkat Kemiskinan } \\
& \rho=\text { Koefisien regresi } \\
& \mathcal{E}=\text { Error }
\end{aligned}
$$

Persamaan diihitung pada tingkat signifikansi 0,05. Analisis persamaan di atas dilakukan dengan bantuan Program SPSS versi 17.0. 


\section{Hasil DAN PEMBAHASAN}

\section{Pengaruh Langsung Pengeluaran Anggaran Bidang Pendidikan (X1) terhadap Pengangguran terbuka (Y1) Di Kalimantan Timur}

Pengeluaran Anggaran Bidang Pendidikan (X1) merupakan variabel yang tidak memiliki pengaruh dominan terhadap Pengangguran Terbuka di Kalimantan Timur. Jika dilihat dari hasil uji $\mathrm{t}$ secara parsial dapat diperoleh thitung dengan nilai Pengeluaran Anggaran Bidang Pendidikan, -1,382 $<$ 2,446 dengan taraf signifikan 0,216. Hal ini menunjukkan bahwa variabel Pengeluaran Anggaran Bidang Pendidikan berpengaruh tidak signifikan terhadap Pengangguran Terbuka. Hasil analisis pengaruh langsung Pengeluaran Anggaran Bidang Pendidikan (X1) terhadap Pengangguran Terbuka di Kalimantan Timur menunjukkan bahwa koefisien jalur antara Pengeluaran Anggaran Bidang Pendidikan terhadap Pengangguran Terbuka sebesar $-0,570$, yang artinya jalur tersebut berpengaruh negatif dan tidak signifikan.

Hasil penelitian tersebut berbeda dengan penelitian Imarotus Suaidah dan Hendry Cahyono (2013) yang melakukan penelitian Pengaruh Tingkat Pendidikan Terhadap Tingkat Pengangguran Di Kabupaten Jombang menunjukkan bahwa tingkat pendidikan berpengaruh signifikan terhadap tingkat pengangguran di Kabupaten Jombang. Hal ini sesuai dengan hasil uji t yang mengatakan bahwa variabel tingkat pendidikan berpengaruh signifikan terhadap tingkat pengangguran. Adapun variabel tingkat pendidikan terhadap tingkat pengangguran berpengaruh secara positif. Hasil ini sesuai dengan teori dan penelitian terdahulu yang menjadi landasan teori dalam penelitian ini. Peneliti menyimpulkan bahwa tingkat pendidikan yang tinggi akan mencari pekerjaan di daerah yang memiliki leading sector sesuai dengan pendidikannya, karena hal ini akan lebih leluasa bersaing di daerah atau propinsi lain yang leading sektor usaha sesuai pendidikan ditunggu yang dimiliki seorang tersebut. Hal ini bertentangan dengan teori human capital dimana seseorang dapat meningkatkan penghasilannya melalui peningkatan pendidikan. Setiap tambahan satu tahun sekolah berarti, di satu pihak, meningkatkan kemampuan kerja dan tingkat penghasilan selama satu tahun dalam mengikuti sekolah tersebut. Di samping penundaan menerima penghasilan tersebut, orang yang melanjutkan sekolah harus membayar biaya secara langsung seperti uang sekolah, pembelian buku-buku dan alat-alat sekolah. Namun penelitian ini tidak membahas bagaimana pengaruh pengeluran pemerintah bisa juga berpengaruh terhadap tingkat pengangguran.

Dalam penelitian ini, ternyata penyebab utama mengapa Pengeluaran Anggaran Bidang Pendidikan berpengaruh negatif tidak signifikan terhadap Pengangguran Terbuka di Provinsi Kalimantan Timur, Pemberian Pengeluaran anggaran yang tinggi untuk sektor pendidikan belum dapat menciptakan lapangan kerja baru yang mampu menekan tingkat pengangguran terbuka. Justru kemungkinan besar akan menambah pengangguran intelektual yang tercipta dari lulusan pendidikan yang kurang siap kerja dan profesional. Hal ini lah yang membuat pengaruh Pengeluaran anggaran bidang pendidikan tidak berpengaruh secara signifikan terhadap menekan jumlah pengangguran terbuka.

\section{Pengaruh Langsung Pengeluaran Anggaran Bidang Kesehatan (X2) Terhadap Pengangguran Terbuka (Y1) Di Kalimantan Timur}

Pengeluaran Anggaran Bidang Kesehatan (X2) merupakan variabel yang memiliki pengaruh dominan terhadap Pengangguran Terbuka di Kalimantan Timur. Jika dilihat dari hasil uji t secara parsial dapat diperoleh thitung dengan nilai Pengeluaran Anggaran Bidang Kesehatan, -2,487 > 2,446 dengan taraf signifikan 0,047. Hal ini menunjukkan bahwa variabel Pengeluaran Anggaran Bidang Kesehatan berpengaruh signifikan terhadap Pengangguran Terbuka. Hasil analisis pengaruh langsung Pengeluaran Anggaran Bidang Kesehatan (X2) terhadap Pengangguran Terbuka di Kalimantan Timur menunjukkan bahwa koefisien jalur antara Pengeluaran Anggaran Bidang Kesehatan terhadap Pengangguran Terbuka sebesar $-0,800$, yang artinya jalur tersebut berpengaruh negatif dan signifikan.

Berdasarkan Penelitian Deris Dermawan (2011) yang meneliti tentang pengaruh Pengeluaran anggaran bidang pendidikan dan kesehatan dalam APBN terhadap Kemiskinan di Indonesia. Menyatakan Pada pengeluaran pemerintah sektor kesehatan juga berpengaruh nyata terhadap tingkat kemiskinan di Indonesia, sehingga upaya yang perlu dilakukan oleh pemerintah yakni terus 
meningkatkan pengeluaran pada sektor kesehatan dari tahun ke tahun. Dengan cara mengPengeluarankan pengeluaran sektor kesehatan bagi rakyat kecil melalui program-program yang telah ada dan meningkatkan sarana dan prasarana kesehatan bagi masyarakat yang kurang mampu. Dalam penelitian tersebut, Pengeluaran pemerintah sektor kesehatan berpengaruh nyata terhadap tingkat Kemiskinan di Indonesia. Dimana pada saat pengeluaran pemerintah sektor kesehatan dinaikkan sebesar 1\% akan mengurangi tingkat kemiskinan sebesar 0,1\%. Lincolind Arsyad (1997) dalam penelitian Agung Prastopo (2011) kemiskinan dan pengangguran, menyatakan bahwa ada hubungan yang erat sekali antara tingginya tingkat pengangguran dan kemiskinan. Bagi sebagian besar masyarakat, yang tidak mempunyai pekerjaan tetap atau hanya part-time berada diantara kelompok masyarakat yang sangat miskin. Masyarakat yang bekerja dengan bayaran tetap di sektor pemerintah dan swasta biasanya termasuk diantara kelompok masyarakat kelas menengah keatas. Setiap orang yang tidak mempunyai pekerjaan adalah miskin, sedangkan yang bekerja secara penuh adalah orang kaya. Namun, kadang kala terdapat pekerja diperkotaan yang tidak bekerja secara sukarela karena mencari pekerjaan yang lebih baik dan lebih sesuai dengan tingkat pendidikannya. Mereka menolak pekerjaan-pekerjaan yang mereka rasakan lebih rendah dan mempunyai sumber-sumber lain yang bisa membantu masalah keuangan mereka. Orang-orang seperti ini bisa disebut menganggur tetapi belum tentu miskin. Sama juga dengan banyaknya induvidu yang mungkin bekerja secara penuh per hari, tetapi tetap memperoleh pendapatan sedikit. Banyak pekerja yang mandiri disektor informal, bekerja secara penuh tetapi mereka sering masih tetap miskin.

Dian Octaviani (2001) dalam Penelitian Agung Prastopo (2011) mengatakan bahwa sebagian rumah tangga di Indonesia memiliki ketergantungan yang sangat besar atas pendapatan gaji atau upah yang diperoleh saat ini. Hilangnya lapangan pekerjaan menyebabkan berkurangnya sebagian besar penerimaan yang digunakan untuk membeli kebutuhan sehari-hari. Lebih jauh, jika masalah pengangguran ini terjadi pada kelompok masyarakat berpendapatan rendah (terutama kelompok masyarakat dengan tingkat pendapatan sedikit berada di atas garis kemiskinan), maka insiden pengangguran dengan mudah menggeser posisi mereka menjadi kelompok masyarakat miskin. Artinya, semakin tinggi tingkat pengganguran akan meningkatkan kemiskinan.

\section{Pengaruh Langsung Pengeluaran Anggaran Bidang Infrastruktur (X3) Terhadap Pengangguran terbuka (Y1) Di Kalimantan Timur}

Pengeluaran Anggaran bidang Infrastruktur (X3) merupakan variabel yang tidak memiliki pengaruh dominan terhadap Pengangguran terbuka di Kalimantan Timur. Jika dilihat dari hasil uji $\mathrm{t}$ secara parsial dapat diperoleh thitung dengan nilai Pengeluaran Anggaran Bidang Infrastruktur - 0,039 $<$ 2,446 dengan taraf signifikan 0,970. Hal ini menunjukkan bahwa variabel Pengeluaran Anggaran Bidang Infrastruktur berpengaruh tidak signifikan terhadap pengangguran terbuka. Hasil analisis pengaruh langsung Pengeluaran Anggaran bidang Infrastruktur (X3) terhadap Pengangguran Terbuka di Kalimantan Timur menunjukkan bahwa koefisien jalur antara Pengeluaran Anggaran bidang Infrastruktur terhadap Pengangguran Terbuka sebesar $-0,013$, yang artinya jalur tersebut berpengaruh negatif dan tidak signifikan.

Menurut Arianto A. Patunru (2007) sebagian besar penganggur di Indonesia memiliki tingkat pendidikan tamat SMA atau lebih tinggi. Prosentase penganggur yang memiliki pendidikan tamat SD atau lebih rendah jauh lebih kecil dibanding tamatan SMP ke atas atau SMA keatas. Pengangguran kita membuat program pembangunan infrastruktur. Logianya: resep Keynesian ini akan menyediakan lapangan kerja bagi banyak orang. Dan pengangguran pun berkurang. Sayangnya kita tak boleh terlalu cepat menyimpulkan apakah program pembangunan infrastruktur cocok dengan karakteristik penganggur seperti ini Dapatkah kita mengurangi pengangguran melalui program pembangunan infrastruktur, seperti pembangunan jalan atau infrastruktur pedesaan Sudah menjadi mantera, yang dipercaya mayoritas, bahwa program infrastruktur akan mampu mengatasi pengangguran.

Struktur penganggur yang relatif terdidik, muda, masih tinggal bersama orang tua seperti yang ditunjukkan gambar diatas dan juga, sulit untuk diharapkan mayoritas kelompok ini bersedia bekerja di dalam program infrastruktur sebagai buruh konstruksi. Jenis pekerjaan buruh konstruksi seperti itu akan cocok dengan mereka yang tingkat pendidikannya SD atau lebih rendah. Mereka yang memiliki tingkat pendidikan yang relatif tinggi akan sangat enggan untuk masuk ke pasar kerja seperti ini. 
Kecuali jika mereka telah menjadi begitu miskin, dan tak lagi memiliki non-labour income. Artinya, argumen bahwa pembangunan infrastruktur akan menyelesaikan masalah pengangguran, tampaknya hanya benar sebagian. Ia hanya bisa menyediakan lapangan kerja bagi sebagian kelompok penganggur (dengan pendidikan SD kebawah). Proyek infrastruktur mungkin akan bermanfaat untuk menyediakan lapangan kerja bagi mereka yang miskin dan berpendidikan rendah. Program pembangunan infrastruktur mungkin akan menolong program pengentasan kemiskinan, tapi tak sepenuhnya cocok bagi penciptaan lapangan kerja untuk mereka yang berpendidikan, misalnya SMA keatas, yang merupakan porsi terbesar dari kelompok penganggur ini.

Mereka yang berpendidikan hanya akan bersedia bekerja pada sektor formal. Dan penyerapan pekerja ke sektor formal hanya akan terjadi jika ekonomi di sektor formal tumbuh cepat dan kekakuan pasar tenaga kerja yang mencegah masuknya orang ke sektor formal diatasi. Bukan hanya dengan sekedar menyediakan lapangan kerja bagi buruh konstruksi melalui program infrastruktur seperti yang kita percaya selama ini.

\section{Pengaruh Langsung Pengeluaran Anggaran Bidang Pendidikan (X1) Terhadap Tingkat Kemiskinan (Y2) Di Kalimantan Timur}

Hasil analisis menunjukkan bahwa koefisien jalur antara (X1) 0,239, jalur ini berpengaruh tidak signifikan karena nilai thitung sebesar 0,523, sementara ttabel sebesar 2,570 (thitung 0,523 < ttabel 2,570), dengan demikian pada pola hubungan langsung ini, Pengeluaran Anggaran Bidang Pendidikan berpengaruh positif tidak signifikan terhadap Kemiskinan, yang didukung oleh Probability Value (sig) 0,623>0,050. Hasil analisis pengaruh langsung Pengeluaran Anggaran Bidang Pendidikan (X1) terhadap Kemiskinan di Kalimantan Timur menunjukkan bahwa koefisien jalur antara Pengeluaran Anggaran Bidang Pendidikan terhadap Kemiskinan sebesar 0,239, yang artinya jalur tersebut berpengaruh positif dan tidak signifikan.

Sebagai perbandingan penelitian dari Adi Widodo, Waridin, dan Johanna Maria K. (2011) Secara garis besar, Pengeluaran pengeluaran pemerintah di sektor pendidikan dan kesehatan di kabupaten/kota di Provinsi Jawa Tengah menunjukkan kecenderungan yang meningkat. Demikian pula dengan indikator yang berkaitan dengan pembangunan manusia,seperti angka harapan hidup, angka melek huruf, rata-rata lama sekolah, dan pengeluaran per kapita perbulan; menunjukkan kecenderungan yang meningkat pula. Peningkatan pengeluaran pemerintah di sektor pendidikan dan kesehatan maupun indikator pembangunan manusia, dibarengi dengan semakin membaiknya indikator kemiskinan yang ditandai dengan semakin menurunnya indikator jumlah dan persentase penduduk miskin. Namun sasaran utama dari variabel Pengeluaran Anggaran Bidang Pendidikan dan kesehatan ialah untuk meningkatkan IPM. Kemudian setelah keadaan IPM membaik barulah dapat dilihat kondisi kemiskinan akan berkurang juga. Sehingga dalam penelitian ini variabel Pengeluaran anggaran bidang pendidikan berpengaruh positif namun tidak signifikan terhadap perubahan tingkat kemiskinan.

\section{Pengaruh Langsung Pengeluaran Anggaran Bidang Kesehatan (X2) Terhadap Kemiskinan (Y2) Di Kalimantan Timur}

Hasil analisis menunjukkan bahwa jalur ini berpengaruh signifikan karena nilai thitung sebesar 2,930, sementara itu ttabel sebesar 2.570 (thitung -2,930 > ttabel 2,570), dengan demikian pada pola hubungan langsung ini, Pengeluaran Anggaran Bidang Kesehatan berpengaruh negatif dan signifikan terhadap Kemiskinan, yang didukung oleh Probability Value (sig) $0,033<0,050$. Hasil analisis pengaruh langsung Pengeluaran Anggaran Bidang Kesehatan (X2) terhadap Pengangguran Terbuka di Kalimantan Timur menunjukkan bahwa koefisien jalur antara Pengeluaran Anggaran Bidang Kesehatan terhadap Tingkat Kemiskinan sebesar $-0,888$, yang artinya jalur tersebut berpengaruh negatif dan signifikan. Artinya, kebijakan daerah yang telah diupayakan dengan pengaturan pola pembelanjaan yang proporsional, efisien dan efektif dalam upaya tersebut sudah tepat sasaran. Seperti halnya dari segi kesehatan, Pemerintah dalam hal ini telah mengupayakan semaksimal mungkin untuk pengeluaran anggaran untuk kesehatan, namun faktanya dilapangan masih banyak masyarakat yang kurang mampu belum bisa menikmati pelayanan dari rumah sakit secara maksimal. 


\section{Pengaruh Langsung Pengeluaran Anggaran Bidang Infrastruktur (X3) Terhadap Kemiskinan (Y2) Di Kalimantan Timur}

Hasil analisis menunjukkan bahwa jalur berpengaruh tidak signifikan karena nilai thitung sebesar $-0,231$ sementara ttabel sebesar 2,570 (thitung -0,231 < ttabel 2,570), dengan demikian pada pola hubungan langsung ini, Pengeluaran Anggaran Bidang Infrastruktur berpengaruh negatif tidak signifikan terhadap Pengangguran, yang didukung oleh Probability Value (sig) 0,826 > 0,050. Hasil analisis pengaruh langsung Pengeluaran Anggaran Bidang Infrastuktur (X3) terhadap Kemiskinan di Kalimantan Timur menunjukkan bahwa koefisien jalur antara Pengeluaran Anggaran Bidang Infrastruktur terhadap kemiskinan sebesar -0,075, yang artinya jalur tersebut berpengaruh negatif dan tidak signifikan.

BPS mencatat rencana Pembangunan Jangka Menengah Nasional (RPJMN) 2010-2014 telah menggariskan bahwa Visi Pembangunan 2010-2014 adalah "Terwujudnya Indonesia yang Sejahtera, Demokratis, dan Berkeadilan" (Kementrian Keuangan, 2011). Visi pembangunan tersebut kemudian dijadikan landasan bagi pemerintah dalam mengambil berbagai kebijakan. Salah satunya adalah penerapan program Percepatan Pembangunan Infrastruktur Pedesaan Daerah Tertinggal (P2IPDT) yang dilaksanakan oleh pemerintah melalui Kementrian Pembangunan Daerah Tertinggal (PDT). Kebijakan tersebut dilakukan mengingat masih banyaknya kabupaten yang masuk kategori sebagai daerah tertinggal di Indonesia (183 kabupaten atau sekitar 40,39\%) dan masih tingginya rata-rata persentase jumlah penduduk miskin di daerah tertinggal (sebesar 17,47\% pada tahun 2009). Angka kemiskinan yang tinggi di kabupaten tertinggal ini ternyata diikuti oleh kinerja perekonomian yang buruk. Data empiris menunjukkan bahwa pada tahun 2009, rata-rata PDRB kabupaten tertinggal di wilayah KBI hanya sebesar Rp Rp 1.997,05 juta atau sekitar 42,23 persen dari rata-rata nasional, sedangkan rata-rata PDRB kabupaten tertinggal di wilayah KTI hanya sebesar Rp 1.189,09 juta atau sekitar 25,14 persen dari rata-rata nasional. Perbedaan yang cukup signifikan dari rata-rata output, baik di wilayah KBI maupun KTI dengan rata-rata nasional ini mengindikasikan bahwa di Indonesia masih terjadi ketimpangan pembangunan ekonomi yang cukup besar. Ketimpangan pembangunan ekonomi tersebut juga diikuti dengan ketimpangan pendapatan rumahtangga. Pada Tahun 2008, angka gini rasio Indonesia adalah sebesar 0,37 dimana menurut Todaro (2006), angka ini sudah tidak lagi mencerminkan pendapatan masyarakat yang relatif merata.

\section{Pengaruh Langsung Pengangguran Terbuka (Y1) Terhadap Tingkat kemiskinan (Y2) Di Kalimantan Timur}

Hasil analisis menunjukkan bahwa koefisien jalur antara (Y1) 0,248 , jalur ini berpengaruh tidak signifikan karena nilai thitung sebesar 0,631 sementara ttabel sebesar 2,570 (thitung $=0,631>$ ttabel $=2,570$ ), dengan demikian pada pola hubungan langsung ini, Pengangguran Terbuka berpengaruh positif tidak signifikan terhadap Kemiskinan, yang didukung oleh Probability Value (sig) 0,555 < 0,050. Hasil analisis pengaruh langsung Pengangguran Terbuka (Y1) terhadap Kemiskinan di Kalimantan Timur menunjukkan bahwa koefisien jalur antara Pengangguran terbuka sebesar 0,248, yang artinya jalur tersebut berpengaruh positif dan tidak signifikan.

Menurut Sadono Sukirno (2004), efek buruk dari pengangguran adalah mengurangi pendapatan masyarakat yang pada akhirnya mengurangi tingkat kemakmuran yang telah dicapai seseorang. Semakin turunnya kesejahteraan masyarakat karena menganggur tentunya akan meningkatkan peluang mereka terjebak dalam kemiskinan karena tidak memiliki pendapatan. Apabila pengangguran di suatu negara sangat buruk, kekacauan politik dan sosial selalu berlaku dan menimbulkan efek yang buruk bagi kesejahteraan masyarakat dan prospek pembangunan ekonomi dalam jangka panjang.

Lincolin Arsyad (1997) menyatakan bahwa ada hubungan yang erat sekali antara tingginya tingkat pengangguran dan kemiskinan. Bagi sebagian besar masyarakat, yang tidak mempunyai pekerjaan tetap atau hanya part-time selalu berada diantara kelompok masyarakat yang sangat miskin. Masyarakat yang bekerja dengan bayaran tetap di sektor pemerintah dan swasta biasanya termasuk diantara kelompok masyarakat kelas menengah keatas. Setiap orang yang tidak mempunyai pekerjaan adalah miskin, sedangkan yang bekerja secara penuh adalah orang kaya. Karena kadangkala ada juga pekerja di perkotaan yang tidak bekerja secara sukarela karena mencari pekerjaan yang lebih baik dan 
yang lebih sesuai dengan tingkat pendidikannya. Mereka menolak pekerjaan-pekerjaan yang mereka rasakan lebih rendah dan mereka bersikap demikian karena mereka mempunyai sumber-sumber lain yang bisa membantu masalah keuangan mereka. Orang-orang seperti ini bisa disebut menganggur tetapi belum tentu miskin. Sama juga halnya adalah, banyaknya individu yang mungkin bekerja secara penuh per hari, tetapi tetap memperoleh pendapatan yang sedikit. Banyak pekerja yang mandiri disektor informal yang bekerja secara penuh tetapi mereka sering masih tetap miskin.

\section{Pengaruh Tidak Langsung Pengeluaran Anggaran Bidang Pendidikan (X1) Terhadap Kemiskinan (Y2) Melalui Pengangguran Terbuka (Y1) Di Kalimantan Timur}

Dari Hasil Analisis Uji pengaruh tidak langsung, didapat Pengaruh Pengeluaran Anggaran Bidang pendidikan (X1) terhadap Kemiskinan (Y2) melalui Pengangguran Terbuka (Y1) sebesar 0,14136 (negatif). Artinya Pengeluaran Anggaran Bidang Pendidikan tidak berpengaruh secara negatif tidak signifikan terhadap kemiskinan melalui pengangguran terbuka. Jadi pengPengeluaranan anggaran yang tinggi untuk mengurangi kemiskinan terbukti tidak berpengaruh.

Pengaruh tidak langsung Pengeluaran Anggaran Bidang Pendidikan terhadap Kemiskinan melalui pengangguran terbuka di Kalimantan Timur menunjukkan hubungan yang negatif dan tidak signifikan. Hal ini menujukkan bahwa adanya Pengeluaran Anggaran Bidang Pendidikan belum memberikan kontribusi terhadap peningkatan taraf kesejahteraan masyarakat di Kalimantan Timur. Walaupun dari sisi intelektual banyak masyarakat yang memiliki tingkat lulusan yang tinggi. Namun, belum bisa menjamin pemberantasan kemiskinan jika lulusan tersebut masih mengalami pengangguran intelktual, jika jumlah lapangan pekerjaan yang ada tidak menyimnagi tingkat lulusan tersebut.

\section{Pengaruh Tidak Langsung Pengeluaran Anggaran Bidang Kesehatan (X2) Terhadap Kemiskinan (Y2) Melalui Penagngguran Terbuka (Y1) Di Kalimantan Timur}

Dari Hasil Analisis Uji pengaruh tidak langsung, didapat Pengaruh Pengeluaran Anggaran Bidang Kesehatan (X2) terhadap Kemiskinan (Y2) melalui Pengangguran Terbuka (Y1) sebesar 0,1984. Pengaruh tidak langsung Pengeluaran Anggaran Bidang Kesehatan terhadap Kemiskinan melalui Pengangguran Terbuka di Kalimantan Timur, dalam hal ini menunjukkan hubungan yang negatif dan signifikan. Artinya bahwa apabila terjadi peningkatan pada Pengeluaran Anggaran Bidang Kesehatan, maka akan mempengaruhi tingkat kemiskinan. Hal ini bisa terjadi karena fasilitas kesehatan sudah bisa dirasakan seluruh masyarakat kaltim dengan baik. Terlebih fasilitas kesehatan gratis yang sangat membantu pengeluaran keluarga miskin.

\section{Pengaruh Tidak Langsung Pengeluaran Anggaran Bidang Infrastruktur (X3) Terhadap Kemiskinan (Y2) Melalui Pengangguran Terbuka (Y1) Di Kalimantan Timur}

Dari Hasil Analisis Uji pengaruh tidak langsung, didapat Pengaruh Tidak Langsung Pengeluaran Anggaran Bidang Infrastruktur (X3) Terhadap Kemiskinan (Y2) Melalui Pengangguran Terbuka (Y1) yaitu sebesar -0,003224. Pengaruh Tidak Langsung Pengeluaran Anggaran Bidang Infrastruktur Terhadap Kemiskinan Melalui Pengangguran Terbuka di Kalimantan Timur menunjukkan hubugan negatif dan tidak signifikan. Hasil ini berbeda dengan Susilo Bambang Yudhoyono (2004) dengan judul "Menganalisis dampak penerapan kebijakan fiskal, terutama pengeluaran pemerintah terhadap pengangguran dan kemiskinan" menyatakan. Hasil simulasi menunjukkan bahwa peningkatan pengeluaran pemerintah untuk pembangunan infrastruktur berdampak positif terhadap pertumbuhan ekonomi dan penyerapan tenaga kerja, sehingga dapat mengurangi pengangguran. Untuk mengurangi kemiskinan, khususnya di perdesaan, diperlukan policy mix antara pengeluaran pemerintah untuk pembangunan pertanian dan kebijakan upah. 


\section{SIMPULAN}

Berdasarkan hasil analisis, pembahasan dan pengujian hipotesis, dapat ditarik beberapa kesimpulan sebagai berikut:

1. Peningkatan Pengeluaran Pemerintah Bidang Pendidikan berpengaruh negatif tidak signifikan terhadap Pengangguran Terbuka di Kalimantan Timur, dapat disimpulkan ada dampak dari peningkatan alokasi anggaran untuk pendidikan namun masih rendah dalam menciptakan lapangan pekerjaan di Kalimantan Timur. Hal ini disebabkan jumlah lulusan yang ada masih teridentifikasi sebagai pengangguran terbuka karena jumlah lapangan pekerjaan tidak bisa mengimbangi jumlah lulusan di Kalimantan Timur.

2. Peningkatan Pengeluaran Pemerintah Bidang Kesehatan berpengaruh negatif dan signifikan terhadap penurunan Pengangguran Terbuka di Kalimantan Timur, dapat disimpulkan ada dampak yang signifikan dari alokasi anggaran bidang kesehatan terhadap penurunan pengangguran di Kalimantan Timur. Karena masih sudah seimbangnya lulusan bidang kesehatan dengan lapangan kerja bidang kesehatan, sehingga pengeluaran pemerintah bidang kesehatan sudah bisa memberikan sumbangsih terhadap pengurangan pengangguran terbuka secara signifikan.

3. Peningkatan Pengeluaran Pemerintah Bidang Infrastruktur berpengaruh negatif tidak signifikan terhadap kenaikan Pengangguran Terbuka di Kalimantan Timur. Dapat disimpulkan jika anggaran infrastruktur naik maka pengangguran akan turun. Artinya Pengeluaran Pemerintah bidang infrastruktur sudah memberikan dampak secara langsung, namun masih rendah dalam penurunan pengangguran di Kalimantan Timur karena masih minimnya pembangunan infrastruktur. Karena pembangunan infrastruktur masih fokus dikota-kota besar.

4. Peningkatan Pengangguran Terbuka berpengaruh positif namun tidak signifikan terhadap peningkatan Kemiskinan di Kalimantan Timur, Dapat diasumsikan jika Pengangguran Terbuka naik maka Kemiskinan akan naik juga. Ada dampak dari peningkatan pengangguran terbuka namun masih rendah terhadap peningkatan penduduk miskin di Kalimantan Timur. Dapat diasumsikan meskipun warga Kalimantan Timur menganggur tapi belum berada dalam garis kemiskinan.

5. Peningkatan Pengeluaran Pemerintah Bidang Pendidikan berpengaruh positif tidak signifikan terhadap peningkatan kemiskinan di Kalimantan Timur. Dapat diasumsikan anggaran pendidikan meningkat dan kemiskinan juga meningkat. Artinya ada dampak namun masih rendah dari Pengeluaran Pemerintah pendidikan dalam menekan peningkatan kemiskinan di Kalimantan Timur. Karena lapangan pekerjaan yang saat ini ada semakin berkurang tidak seimbang dengan pembukaan lapangan pekerjaan baru, sehingga masyarakat miskin yang terdidik semakin banyak.

6. Peningkatan Pengeluaran Pemerintah Bidang Kesehatan berpengaruh negatif dan signifikan terhadap penurunan tingkat kemiskinan di Kalimantan Timur. Dimana anggaran kesehatan meningkat dan kemiskinan mengalami penurunan. Ada dampak yang signifikan dari alokasi anggaran kesehatan dalam menekan angka kemiskinan di Kalimantan Timur. Karena fasilitas kesehatan sudah menyentuh semua warga miskin di Kalimantan Timur.

7. Peningkatan Pengeluaran Pemerintah Bidang Infrastruktur berpengaruh negatif tidak signifikan terhadap penurunan Tingkat kemiskinan di Kalimantan Timur. Dapat disimpulkan anggaran infrastruktur meningkat dan kemiskinan menurun. Artinya ada dampak dalam hal menurunkan angka kemiskinan namun masih rendah karena masih terjadi ketimpangan pembangunan infrastruktur di Kalimanatan Timur.

8. Peningkatan Pengeluaran Pemerintah Bidang Pendidikan berpengaruh negatif tidak signifikan terhadap Penurunan Kemiskinan melalui penurunan Pengangguran Terbuka di Kalimantan Timur. namun sudah dampak dalam hal menurunkan angka kemiskinan melalui penurunan penagguran terbuka, namun masih rendah karena masih sedikit jumlah lapangan pekerjaan untuk mengimbangi tingkat kelulusan yang siap mencari pekerjaan.

9. Peningkatan Pengeluaran Pemerintah Bidang Kesehatan berpengaruh negatif dan signifikan terhadap penurunan Kemiskinan melalui penurunan Pengangguran Terbuka di Kalimantan Timur. Artinya sudah ada dampak dalam hal menurunkan angka kemiskinan melalui penurunan angka 
pengangguran secara signifikan karena fasilitas kesehatan sudah bisa dirasakan masyarakat secara maksimal oleh keluarga miskin.

10. Peningkatan Pengeluaran Pemerintah bidang infrastruktur berpengaruh negatif tidak signifikan terhadap peningkatan Kemiskinan melalui peningkatan Pengangguran Terbuka di Kalimantan Timur Artinya belum ada dampak yang tinggi dalam hal menurunkan angka kemiskinan melalui penurunan angka pengangguran karena masih terjadianya ketimpangan pembangunan infrastruktur di Kalimantan Timur.

\section{DAFTAR PUSTAKA}

Abdul Hakim. 2001. Ekonomi Pembangunan. UII Press. Yogyakarta.

Agusalim. 2007. Peran Anggaran Pemerintah Terhadap Pengurangan Angka Kemiskinan di Indonesia. Ekonomi dan Bisnis. Vol. 10 No. 1

BPS. 2009. Kaltim Dalam Angka 2009

BPS. 2010. Kaltim Dalam Angka 2010

BPS, 2011. Kaltim Dalam Angka 2011

BPS. 2012. Kaltim Dalam Angka 2012

BPS. 2013. Kaltim Dalam Angka 2013

BPS. 2014. Kaltim Dalam Angka 2014

BPS. 2015. Kaltim Dalam Angka 2015

Badan Pembangunan Daerah Kalimantan Timur. 2015. Alokasi Anggaran APBD Untuk Bidang Infrasturktur Provinsi Kalimantan Timur Tahun Anggaran 2005-2014

Bambang, Susilo, Yudhoyono. 2004, Menganalisis dampak penerapan kebijakan fiskal, terutama pengeluaran pemerintah terhadap pengangguran dan kemiskinan. Jakarta.

Desmawan, Deris. 2011. Analisis Pengaruh Pengeluaran Pemerintah Sektor Pendidikan Dan Kesehatan Dalam APBN Terhadap Kemiskinan Di Indonesia. Universitas Lampung, Bandar Lampung.

Dinas Pendidikan Kalimantan Timur. 2015. Rekapitulasi Alokasi Anggaran Fungsi Pendidikan Provinsi Kalimantan Timur Tahun Anggaran 2005-2014

Dina Pertiwi, Lena. Efisiensi Pengeluaran Pemerintah di Provinsi Jawa Tengah periode 1999 dan 2002. 2007.

Dinas Kesehatan Kalimantan Timur. 2015. Rekapitulasi Alokasi Anggaran Fungsi Kesehatan Provinisi Kalimantan Timur Tahun Anggaran 2005-2014

Catur Lestari, Fatin, 2008. Kemiskinan dan Pengeluaran Pemerintah Untuk infrastruktur Indonesia 1976-2006. Institut Pertanian Bogor, Bogor.

Gujarati, Damodar, 1995. Ekonometrika Dasar . Penerbit Erlangga, Jakarta

Gunandi Brata, Aloysius. Investasi Sektor Publik Lokal, Pembangunan Manusia, dan Kemiskinan. 2005

Halim, Abdul, 2002. Akuntansi Keuangan Daerah, Edisi Pertama, Salemba Empat, Jakarta.

Imam, Ghozali, 2011. Aplikasi Analisis Multivanate dengan program IBM SPSS19. Semarang. Badan Penerbit-Undip.

Jhingan, ML. 2000. Ekonomi Pembangunan dan Perencanaan. Edisi Pertama. Raja Grafindo Persada. Jakarta. 
Lincolin Arsyad. 1999. Ekonomi Pembangunan. Edisi Keempat, Bagian Penerbitan STIE YKPN. Yogyakarta.

Mahmudi. 2007. Manajemen Kinerja Bidang Publik. UPP STIM YKPN. Yogyakarta.

Mudrajad Kuncoro. 2000. Ekonomi Pembangunan: Teori, Masalah, dan Kebijakan. UPP AMP YKPN.

Mudrajad Kuncoro. 2004. Otonomi dan Pembangunan Daerah: Reformasi, Perekonomian, Strategi dan Peluang.Penerbit Erlangga. Jakarta.

Musgrave, Richard. A dan Peggy B Musgrave. 1989. Public Finance in Theory and Practise. Fifth Edition, McGraw-Hill Book, International Edition, 1989.

Wibowo, Noviato, Dwi. 2003. Masalah Pengentasan Kemiskinan di Indonesia: Pendekatan Hipotesis Kuznet. Buletin Pangsa. Edisi 10/IX.

Pascual, Merta dan Santiago lvarez Garcla, Government Spending and economic growth in the European union Countries :An empirical Approach. 2006

Patunru, Arianto A. 2007. Benarkah pembangunan infrastruktur mengurangi pengangguran. Jakarta

Prastopo, Agung. 2013 Kemiskinan Dan Pengangguran. Fakultas Ekonomi Universitas Negeri Jakarta. Jakarta Timur.

Priyo Hari Adi, Fhino Andrea Christy. 2009. Hubungan antara Dana Alokasi Umum, Belanja Modal dan kualitas pembangunan manusia. The 3rd national confrence UKWMS. Surabaya.

Sanggelorang, Septiana M. M, Vekie A. Rumate, dan Hanly F.DJ. Siwu. Pengaruh Pengeluaran Pemerintah di Sektor Pendidikan dan Kesehatan Terhadap Indeks Pembangunan Manusia di Sulawesi Utara. Universitas Sam Ratulangi Manado. 2015

Sukirno. Sadono, 2000. Makroekonomi Modern. Raja Grafindo Persada. Jakarta.

Sugerman, 2012. Hubungan pendidikan dan pengangguran. Universitas Gunardarma. Jakarta.

Suaidah, Imarotus dan Hendry Cahyono. 2011. Pengaruh Tingkat Pendidikan Terhadap Tingkat Pengangguran Di Kabupaten Jombang. Fakultas Ekonomi, Unesa, Surabaya.

Stigliz, E. Joseph. 1986. Economic of Public Sector. New York: WW Norton and Company Syaukani, H.R, Affan Gaffar,

Rasyid, Ryas. 2005. Otonomi Daerah dalam Negara Kesatuan Republik Indonesia. Pustaka Pelajar. Cetakan ke IV. Yogyakarta.

Todaro, Michael. (2000). Pembangunan Ekonomi di Dunia Ketiga. Edisi ke-7 (Terjemahan Bahasa Indonesia). Jakarta. PT Erlangga. 